\section{Simple-sequence Repeat Marker Analysis of Genetic Relationships within Hydrangea paniculata}

\author{
Sandra M. Reed ${ }^{1}$ \\ USDA-ARS, Floral and Nursery Plants Research Unit, Tennessee State \\ University Otis L. Floyd Nursery Research Center, 472 Cadillac Lane, \\ McMinnville, TN 37110
}

Timothy A. Rinehart
USDA-ARS, Southern Horticultural Laboratory, 810 Highway 26 West,
Poplarville, MS 39470

Additional index words. breeding, molecular markers, panicle hydrangea

\begin{abstract}
Genetic diversity studies using 26 simple-sequence repeat (SSR) markers were conducted with 36 cultivars, breeding lines, and wild-collected accessions of Hydrangea paniculata Sieb. The SSR markers were highly variable among the genotypes, producing a mean of 5.8 alleles per marker. Three cultivars (Boskoop, Compact Grandiflora, and Webb) were either identical to or sports of the popular cultivar Grandiflora. The name 'Pee Wee' appears to have been applied to two phenotypically different compact forms of $H$. paniculata, one of which seems to be a sport of 'Tardiva', whereas the other is likely derived from 'Grandiflora'. No close genetic similarity was observed among several cultivars from a long-term Belgium breeding program, although many had one parent in common. Early-flowering genotypes clustered separately from genotypes that flower in midsummer, but close genetic relationships were not observed among early-flowering cultivars. Two genotypes from Taiwan were genetically similar but were distinctly different from the Japanese genotypes. These, along with the early-flowering genotypes and a new collection from Japan, may represent unexploited sources of germplasm for improvement of $\boldsymbol{H}$. paniculata.
\end{abstract}

The genus Hydrangea L. consists of $\approx 23$ species and has an American-Asiatic distribution (McClintock, 1957). Several species are cultivated as ornamentals, of which $H$. paniculata is the most cold-hardy (Dirr, 2004). This species, which is also known by the common name of panicle hydrangea, is native to Japan, eastern and southern China, and Taiwan (Dirr, 2004; McClintock, 1957). McClintock (1957) placed H. paniculata in Section Hydrangea Maxim., Subsection Heteromallae Rehder, along with $H$. heteromalla D. Don. Molecular data supported the relationship between these two species and also indicated that they share considerable genetic similarity with Schizophragma Sieb. and Zucc. (Rinehart et al., 2006). Diploid, trip-

Received for publication 25 Aug. 2008. Accepted for publication 7 Oct. 2008.

We thank David Creech and Barbara Stump (Mast Arboretum at Stephen F. Austin State University), Kristin VanHoose (Amethyst Hill Nursery), Don Shadow (Shadow Nurseries), and Mark Widrlechner (North Central Regional Plant Introduction Station) for graciously donating tissue and plants from their collections for this research.

Mention of trade names or commercial products in this article is solely for the purpose of providing specific information and does not imply recommendation or endorsement by the U.S. Department of Agriculture.

${ }^{1}$ To whom reprint requests should be addressed; e-mail Sandra.Reed@ars.usda.gov. loid, tetraploid, and hexaploid forms of Hydrangea paniculata have been reported, but only the tetraploid chromosome number $(2 n=4 x=72)$ has been reported for horticultural forms of the species (Funamoto and Ogawa, 2002; Funamoto and Tanaka, 1988; Haworth-Booth, 1984; Sax, 1931; Van Laere et al., 2008; Zonneveld, 2004).

Hydrangea paniculata is cultivated primarily as a garden plant, but there is also interest in using it in the cut flower industry (Leeson et al., 2004). Most forms grow 3 to $4.5 \mathrm{~m}$ in height with a similar spread and produce long (15 to $20 \mathrm{~cm}$ ) panicles in midsummer. Like with most other members of the genus, $H$. paniculata inflorescences consist of a combination of small, inconspicuous perfect flowers and large, imperfect flowers with showy sepals. Flowers open white or cream-colored, but in some cultivars turn pale to deep pink as they age. Rated as hardy to between -34 to $-37 \mathrm{C}$ (Rose et al., 2001), H. paniculata is recommended for USDA cold-hardiness zones 4 to 8 (Dirr, 2004).

Approximately 50 extant cultivars of $H$. paniculata have been described (Dirr, 2004; Mallet, 1994; Mallet et al., 1992; van Gelderen and van Gelderen, 2004). A few ('Floribunda', 'Grandiflora', 'Kyushu', 'Praecox') originated in Japan and have been in cultivation for over 100 years. Many others were developed through breeding efforts in Europe and have been introduced to the United States only during the past 10 to 15 years. Although many of the $H$. paniculata cultivars available in the United States are relatively recent introductions, little is known about their parentage. In addition to named cultivars, a few wild-collected $H$. paniculata accessions are available in the United States. Two of these were collected in Taiwan and appear to be the only $H$. paniculata germplasm in the United States that was not either introduced from Japan or bred from Japanese germplasm.

Microsatellite, or simple-sequence repeat (SSR), markers provide a useful method for characterizing genetic diversity within a plant species. SSR markers were recently used to study relationships among $114 \mathrm{H}$. macrophylla (Thunb.) Ser. genotypes (Reed and Rinehart, 2007). Genetic similarities were found among remontant, variegated, and double-flowered cultivars. Some presumed synonyms were valid, whereas others were not. Potentially unexploited sources of germplasm within $H$. macrophylla were identified.

The objective of this study was to use SSR markers to study genetic relationships within $H$. paniculata. We were particularly interested in rectifying synonym confusion and possible mislabeling errors and studying relationships between cultivars developed through the same and different breeding programs.

\section{Materials and Methods}

Plant materials. The $36 \mathrm{H}$. paniculata genotypes tested in this study are listed in Table 1 . In addition to 28 cultivars, four wildcollected genotypes (BSWJ 3802, DJHT 99157, HC 970618, PI 479429) and four breeding lines (BL 16-02, BL 22-02, G-881, NA 74383) were examined. Twelve cultivars (Brussels Lace, Floribunda, Grandiflora, Greenspire, Kyushu, Limelight, Pink Diamond, Praecox, Silver Dollar, Tardiva, Unique, and White Lace) included in this study have been reported to be tetraploids (Sax, 1931; Van Laere et al., 2008; Zonneveld, 2004); ploidy level has not been reported for any of the other genotypes. A single plant was used for $26 \mathrm{H}$. paniculata genotypes. Three seedlings of G-881, obtained from openpollinations of 'Dharuma', and two seedlings of DJHT 99157 were analyzed; data from these plants are presented individually. Two or three plants each of 'Brussels Lace', 'Chantilly Lace', 'Floribunda', 'Grandiflora', 'Greenspire', 'Tardiva', 'Unique', and 'White Moth' were analyzed; because all duplicate samples of these cultivars yielded comparable data, data from only one representative are presented. Plant tissue was obtained from plants in our collection at the Nursery Research Center in McMinnville, $\mathrm{TN}$, or from public or commercial sources (Table 1). Four H. heteromalla selections were included in the analysis for rooting the phenogram.

Simple-sequence repeat development and sample processing. Previously described SSR-enriched libraries (Rinehart et al., 2006) were screened for polymorphic loci against a panel of $12 \mathrm{H}$. paniculata cultivars. 
Table 1. Hydrangea paniculata genotypes evaluated with 26 simple-sequence repeat markers and sources of tissue.

\begin{tabular}{|c|c|}
\hline Genotypes & $\begin{array}{c}\text { Source of leaf } \\
\text { tissue }^{z}\end{array}$ \\
\hline Big Ben & $\mathrm{NRC}$ \\
\hline BL 16-02 & MAST \\
\hline BL 22-02 & MAST \\
\hline Boskoop & $\mathrm{NRC}$ \\
\hline Brussels Lace & AHN; NRC \\
\hline BSWJ 3802 & MAST \\
\hline Burgundy Lace & NRC \\
\hline Chantilly Lace & MAST; NRC \\
\hline Compact Grandiflora & MAST \\
\hline Dharuma & NRC \\
\hline DJHT 99157 & NRC \\
\hline Dolly & NRC \\
\hline Quick Fire $^{\mathrm{TM}}$ (Bulk) & $\mathrm{SN}$ \\
\hline Floribunda & MAST; NRC \\
\hline G-881 & $\mathrm{NRC}$ \\
\hline $\begin{array}{l}\text { Grandiflora } \\
\text { (PeeGee; Pee Gee) }\end{array}$ & MAST; NRC \\
\hline Greenspire & AHN; MAST; NRC \\
\hline НC 970618 & MAST \\
\hline Kyushu & NRC \\
\hline Limelight & NRC \\
\hline NA 74383 & NRC \\
\hline Pee Wee & NRC \\
\hline Phantom & $\mathrm{SN}$ \\
\hline PI 479429 & NCRPIP \\
\hline Pink Diamond & NRC \\
\hline $\begin{array}{l}\text { Pinky Winky }{ }^{\top M} \\
\text { (DVPinky) }\end{array}$ & NRC \\
\hline Praecox & MAST \\
\hline Silver Dollar & NRC \\
\hline Tardiva & AHN; NRC \\
\hline The Swan ${ }^{\mathrm{TM}}$ (Barbara) & NRC \\
\hline Unique & AHN; NRC \\
\hline Webb & NRC \\
\hline White Lace & MAST \\
\hline White Lady & $\mathrm{NRC}$ \\
\hline White Moth & MAST; NRC \\
\hline White Tiara & $\mathrm{NRC}$ \\
\hline
\end{tabular}

${ }^{\mathrm{z}} \mathrm{AHN}=$ Amethyst Hill Nursery, Aurora, OR; MAST $=$ Stephen F. Austin MAST Arboretum, Regional Plant Introduction Station, Ames, IA; NRC $=$ Tennessee State University Nursery Research Center, McMinnville, TN; SN = Shadow Nursery, Winchester, TN.

DNA was extracted from $1-\mathrm{cm}^{2}$ pieces of fresh leaf tissue using a Qiagen Plant Mini Kit (Qiagen, Valencia, CA) and quantified using a NanoDrop Spectrophotometer (Nanodrop Technologies, Wilmington, DE). SSR amplification was performed using a modified three-primer protocol (Rinehart et al., 2006). Fluorescence-labeled polymerase chain reaction (PCR) fragments were visualized by automated capillary gel electrophoresis on an ABI3100-Avant or ABI3730xl (Applied Biosystems, Foster City, CA) using ROX-500 size standard. GeneMapper version 4.0 (Applied Biosystems, Foster City, CA) was used to recognize and size peaks. SSR markers are described in Table 2 and all sequences were submitted to the $\mathrm{Na}$ tional Center for Biotechnology Information GenBank.

Data analysis. Data from 26 SSR markers were compiled for the 36 genotypes and analyzed for shared allele frequencies. Nei's minimum genetic distance was calculated for all samples (Nei, 1972). Gene diversity Nacogdoches, TX; NCRPIS $=$ North Central

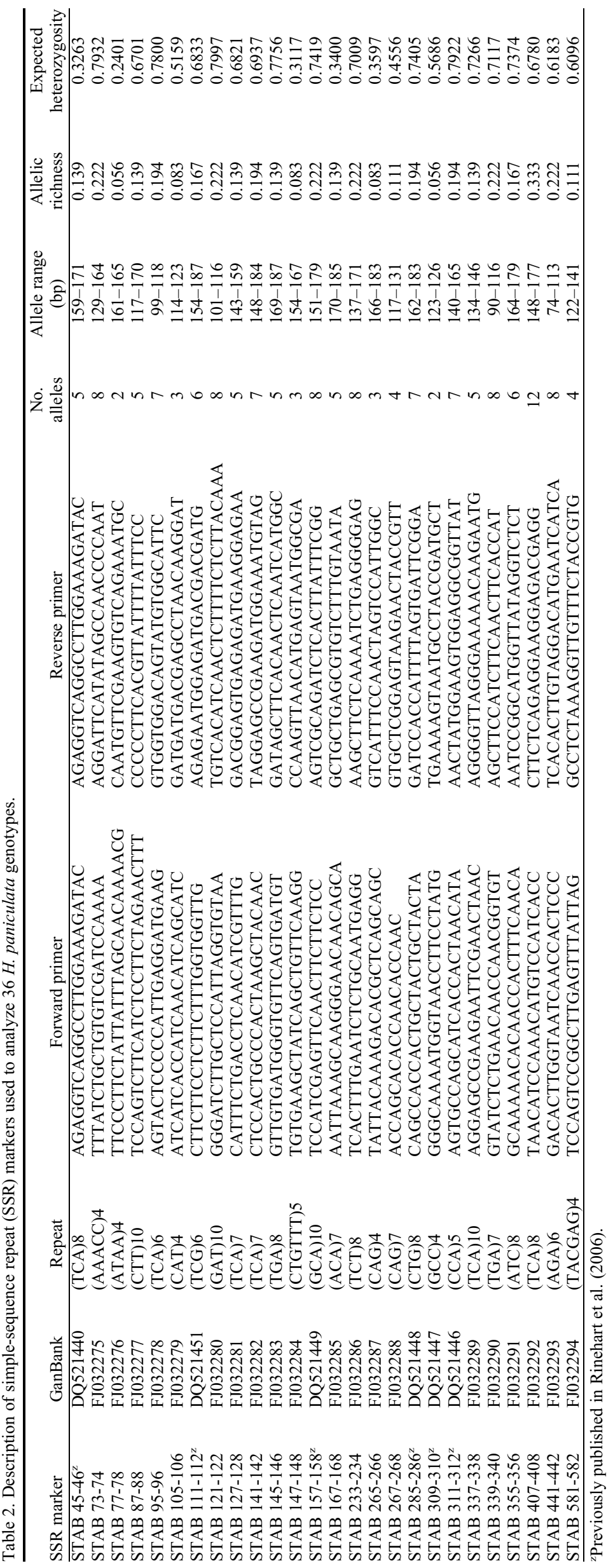


estimates were produced using Nei's 1987 estimator for heterozygosity and expected gene diversity was determined using FSTATS software (Goudet, 1995; Saitou and Nei, 1987). In cases in which two or three peaks were observed for a marker, relative peak height was used to determine how many copies of each allele was present.

POPULATIONS version 1.2.28 was used for phenetic analyses (Langella, 2002). Principal coordinate analysis (PCoA) plots and tree dendograms were based on Nei's minimum genetic distance matrix and plots were generated using NTSys software (Rohlf, 1992). Neighbor-joining with 1000 bootstrap replicates for statistical support was used to generate a tree phenogram, which was visualized with TreeView (Page, 1996). All genotypes were included in the tree dendogram, but only $H$. paniculata germplasm introduced from Japan or cultivars bred from Japanese germplasm were included in the PCoA plot.

\section{Results}

The 26 SSR markers were highly variable among the $H$. paniculata genotypes analyzed (Table 2). The largest number of alleles recovered from any SSR marker was 12 and the average number of alleles per marker was 5.8. Two markers generated only two alleles. Allelic richness, calculated by the number of alleles for each marker divided by the number of samples, ranged from 0.056 to 0.333 . Twenty-two markers were trinucleotide repeats. One marker was tetranucleotide and three were pentanucleotide repeats. Allele size variation corresponded to repeat motif for all markers except for a few rare alleles found only in a few genotypes. The range of alleles found for each SSR marker generally matched the expected sizes predicted by sequence data.

Expected heterozygosity was calculated for each SSR marker and ranged from 0.2401 to 0.7997 . Observed heterozygosity was not calculated because all loci were represented by four alleles making up the tetraploid genome. Including the duplicate samples, but not the $H$. heteromalla genotypes or failed PCR, 5096 alleles were included in this analysis. Of these, 1396 alleles were not visible as separate peaks from markers displaying two or three alleles. Hidden alleles for these markers were confirmed by visual inspection of relative peak heights. Peaks with twice the relative fluorescent units (rfu) indicated two alleles of the same size were amplified and were coded twice in the genotype. For example, 'Greenspire' produced 138, 143, and 148 bp alleles for STAB73-74, a pentanucleotide repeat SSR marker. The peak for the $138 \mathrm{bp}$ allele was twice as high as the 143 and 148 bp alleles and was included twice in the tetraploid genotype for 'Greenspire' for this SSR marker. Similarly, 'Pink Diamond' produced allele sizes of 138 and 143 bp for this SSR marker, both at equal rfu. Both alleles were included twice in the genotype for 'Pink
Diamond' for this marker. Only a single peak was observed for 343 PCR reactions and these were coded as four doses of that particular allele. Four peaks were produced from 668 PCR reactions, as expected from a tetraploid with four unique allele sizes at a particular locus.

Only five of the SSR markers never displayed more than three alleles. Six of the SSR markers never displayed more than two different alleles in any given sample. No SSR marker had a single allele for all samples. The remaining 15 SSR markers showed four different alleles in some genotypes, but never more than four alleles in any genotype. Thus, most of the SSR markers produced data consistent with amplification of all possible alleles, including "hidden alleles," which we included based on peak height.

Not including the $H$. heteromalla and duplicate samples, 17 of the 936 PCR amplifications failed to produce any data and were coded as missing. Ten of these failures occurred with BSWJ 3802 and DJHT 99157 , both of which are wild-collected genotypes from Taiwan and separated from the major cluster of $H$. paniculata cultivars (Fig. 1). Excluding identical genotypes, genetic distances ranged from $3.5 \%$ between 'Unique' and NA $74383 \%$ to $50.8 \%$ between 'Pee Wee'/'Tardiva' and DJHT 99157 (plant 2). Average pairwise genetic distance for the $H$. paniculata genotypes examined in this study was $21.25 \%$ using Nei's minimum genetic distance (Nei, 1972).

The 26 SSR markers used in this study were unable to separate the following four groups of cultivars: Boskoop, Compact Grandiflora, Grandiflora, Webb, and White Lace; White Moth and White Tiara; Pee Wee and Tardiva; and, Burgundy Lace and Kyushu (Fig. 1). Genetic relationships were observed among the following genotypes: 'Unique' and NA 74383; 'Burgundy Lace'/'Kyushu' and 'Greenspire'; 'Limelight' and 'Silver Dollar'; 'Dharuma' and three plants of G-881; and BSWJ 3802 and two plants of DJHT 99157. Other subgroups were observed in the dendrogram but did not have good bootstrap support.

The PCoA plot in Figure 2 does not include $H$. heteromalla samples, BSWJ 3802 , or DJHT 99157 and represents $65 \%$ of the total variation. The two Taiwanese samples, BSWJ 3802 and DJHT 99157, were eliminated from the PCoA because they were outliers that made relationships among the other genotypes more difficult to visualize. Clustering seen in the plot corresponds to the subgroups seen in the tree dendogram (Fig. 1) despite the lack of bootstrap support for most clusters.

\section{Discussion}

Hydrangea paniculata 'Grandiflora', which is often referred to as Pee Gee or PeeGee hydrangea, has long been the standard form of $H$. paniculata in cultivation. Introduced in the 1860 s by von Siebold from Japan, it has large panicles consisting pri- marily of showy, imperfect flowers (Dirr, 2004). The weight of the large inflorescences pulls the slender stems downward giving the plant a distinctive drooping form. The 26 SSR markers used in this study could not separate 'Grandiflora' from 'Boskoop', 'Compact Grandiflora', 'Webb', or 'White Lace' (Fig. 1). 'White Lace' is described as being very similar to 'Brussels Lace', which has upright inflorescences with a mixture of showy and inconspicuous flowers (Dirr, 2004). 'White Lace' will not be included in further discussions of genetic relationships because this indicates that the plant used in this study was likely incorrectly labeled. The other three cultivars may be vegetative sports of 'Grandiflora'. 'Boskoop' no longer appears to be available in commerce, but our specimen is phenotypically very similar to 'Grandiflora'. 'Webb' is described as an improved form of 'Grandiflora' that was selected by J.A. Webb of Huntsville, AL (Dirr, 2004). Based on its name, 'Compact Grandiflora' appears to have originated as a sport of 'Grandiflora' selected for its reduced plant habit.

'Pee Wee' is described by Dirr (2004) as being phenotypically very similar to 'Grandiflora', but shorter and with smaller leaves and finer-textured branches. The 'Pee Wee' plant used for this study could not be separated from 'Tardiva' using our markers (Fig. 1). This 'Pee Wee' specimen has upright inflorescences composed of a mixture of showy and inconspicuous flowers and, other than being reduced in size, appears similar to 'Tardiva'. A search for descriptions and images of 'Pee Wee' on the Internet found both those that matched Dirr's description and those similar to the plant in our collection. We believe that there are at least two compact forms of $H$. paniculata in the trade that are referred to as 'Pee Wee'. The 'Compact Grandiflora' specimen in this study may be the same plant as the 'Pee Wee' described by Dirr. Because there is already a H. quercifolia named 'Pee Wee' and the same cultivar name should not be used for plants in the same genus (Brickell et al., 2004), we recommend that new cultivar names be applied to the two distinctly different compact forms of $H$. paniculata in the trade.

Seven of the cultivars included in this study were introduced by Jelena and Robert De Belder of the Kalmthout Arboretum in Belgium (Dirr, 2004; Mallet, 1994; Mallet et al., 1992; van Gelderen and van Gelderen, 2004). 'Unique' was selected from an openpollinated seedling population of 'Floribunda'. 'Brussels Lace', 'Burgundy Lace', 'Greenspire', and 'Pink Diamond' are seedlings of 'Unique', presumably originating from open-pollinations but possibly from controlled hybridizations. According to patent information, 'Barbara' (The Swan ${ }^{\mathrm{TM}}$ ) was developed from a cross of two unnamed selections (U.S. Patent Office, 2003). No references to the parentage of 'White Moth' could be found. No close genetic relationship was found between any of the De Belders 


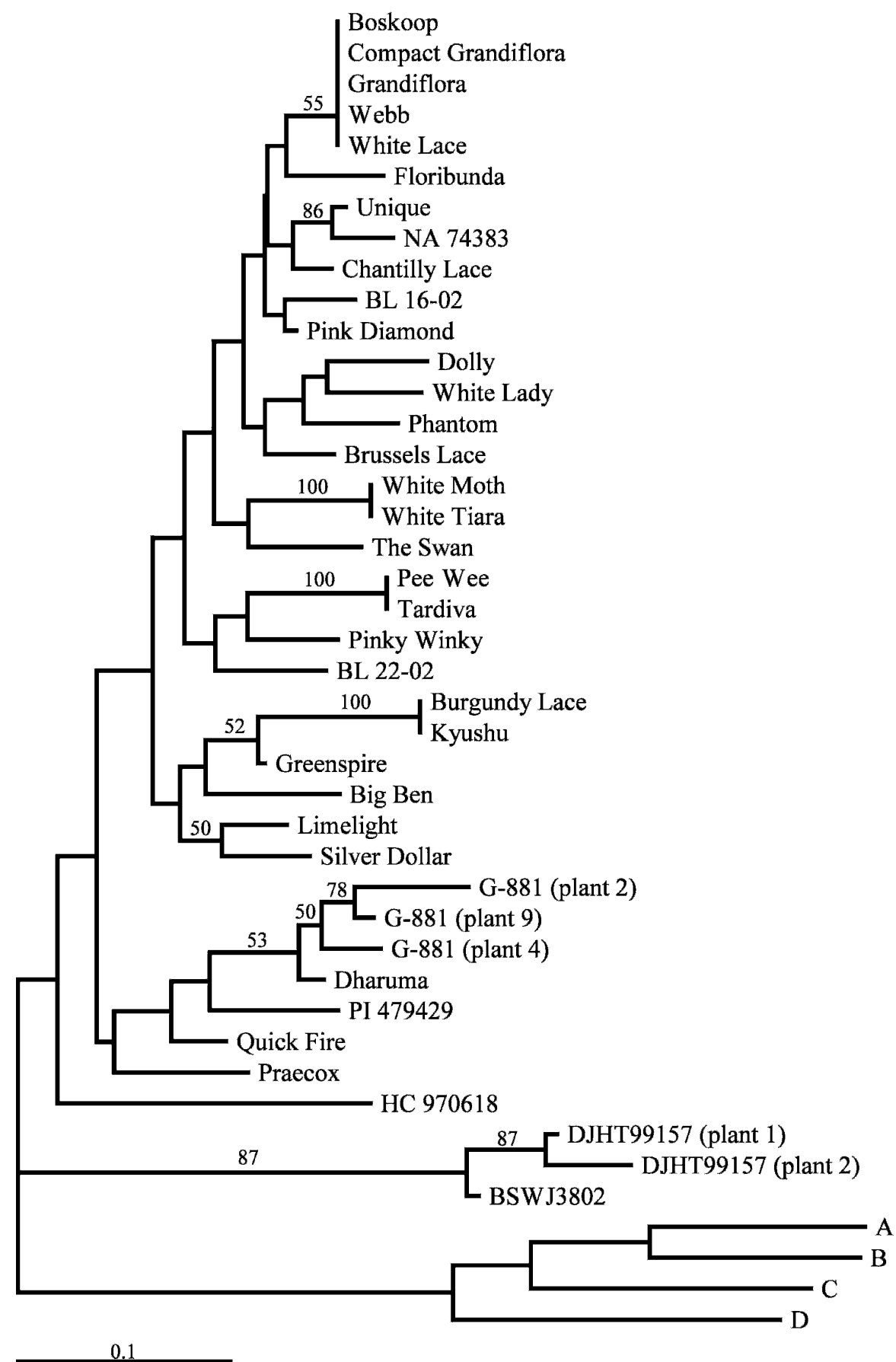

Fig. 1. Neighbor-joining phenogram generated using Nei's minimum genetic distance matrix for 26 singlesequence repeat markers among 36 Hydrangea paniculata genotypes. Bootstrap values out of 1000 replicates are shown if $50 \%$ or higher. Three cultivars are listed by their trademarked names: Early Sensation ('Bulk'), Pinky Winky ('DVPinky'), The Swan ('Barbara'). Tree was rooted with four accessions of $H$. heteromalla: $\mathrm{A}=\mathrm{DJHC} 793 ; \mathrm{B}=\mathrm{HWJCM} 180 ; \mathrm{C}=\mathrm{DJHC}$ 98263; and, $\mathrm{D}=$ var. xanthoneura NA 67857.

cultivars examined, even those in which 'Unique' served as a parent. Presumably, none of these cultivars were full-sibs. Surprisingly, 'Burgundy Lace' appeared identical to 'Kyushu', a cultivar that was introduced from Japan but was distributed by the De Belders (Dirr, 2004; van Gelderen and van Gelderen, 2004). Because only a single plant of both of these cultivars was examined, it is impossible to speculate as to which, if either, plant was mislabeled. strap support was not high, 'Dolly', 'White Lady', and 'Phantom' appear to have a genetic relationship and cluster with 'Limelight' and 'Silver Dollar' in the PCoA (Fig. 2). 'Big Ben' did not appear genetically similar to the other five Zwijnenburg introductions.

'White Tiara' appears genetically identical to 'White Moth'. No information concerning the origins of 'White Tiara' was located and, because the plant from which we took our leaf samples from is no longer alive, no phenotypic comparison between it and 'White Moth' can be made. However, because 'White Tiara' no longer seems to be available in the trade, the need to verify its genetic identity is probably a moot point

Although $H$. paniculata exhibits gametophytic self-incompatibility, it is possible to obtain a few self seedlings (Reed, 2004). NA 74383 is a seedling obtained from controlled self-pollinations of 'Unique' that was selected for its compact growth habit. It shows a close genetic relationship with its parental cultivar. Three open-pollinated seedlings obtained from 'Dharuma' (G-881, plants 2, 4, and 9) were also examined. Based on the morphological similarity of these plants to 'Dharuma', plus the fact that no other $H$. paniculata cultivar was in flower at the same time as 'Dharuma', we had speculated that these seedlings were the result of self-pollination. The SSR marker data support this assumption.

Although most $H$. paniculata cultivars flower in midsummer, a few flower in late spring to early summer. Three early flowering cultivars, Dharuma, Bulk (Quick Fire ${ }^{\mathrm{TM}}$ ), and Praecox, were included in this study. Although bootstrap support was not strong, there did appear to be relationships among these cultivars (Fig. 1). PI 479429, which was selected from a collection made in Japan, also flowers early (Mark Widrlechner, personal communication) and was in the same clade as the other early-flowering genotypes. These four genotypes, along with the three selfprogeny of 'Dharuma', were outside the main cluster of $H$. paniculata cultivars (Fig. 2). In addition to flowering time, 'Dharuma' and PI 479429 differ from most $H$. paniculata cultivars in size, rarely exceeding $1.2 \mathrm{~m}$ in height (Dirr, 2004; Mark Widrlechner, personal communication). However, the inflorescences of these two cultivars are less attractive than those of several of the new, late-flowering introductions such as 'Limelight', 'Silver Dollar', and 'DVPinky' (Pinky Winky ${ }^{\mathrm{TM}}$ ). Although hybridization between the earlyand late-flowering cultivars is difficult because their flowering times do not overlap, this problem could likely be overcome by short-term storage of pollen.

In addition to PI 479429, three other wildcollected accessions were included in this study. Both BSWJ 3802 and DJHT 99157 were collected in Taiwan, the former in 1996 by Bleddyn and Sue Wynn-Jones and the latter in 1999 by Dan Hinkley (Heronswood Nursery, 2000, 2003). Both accessions are described as having bluish green foliage. The 


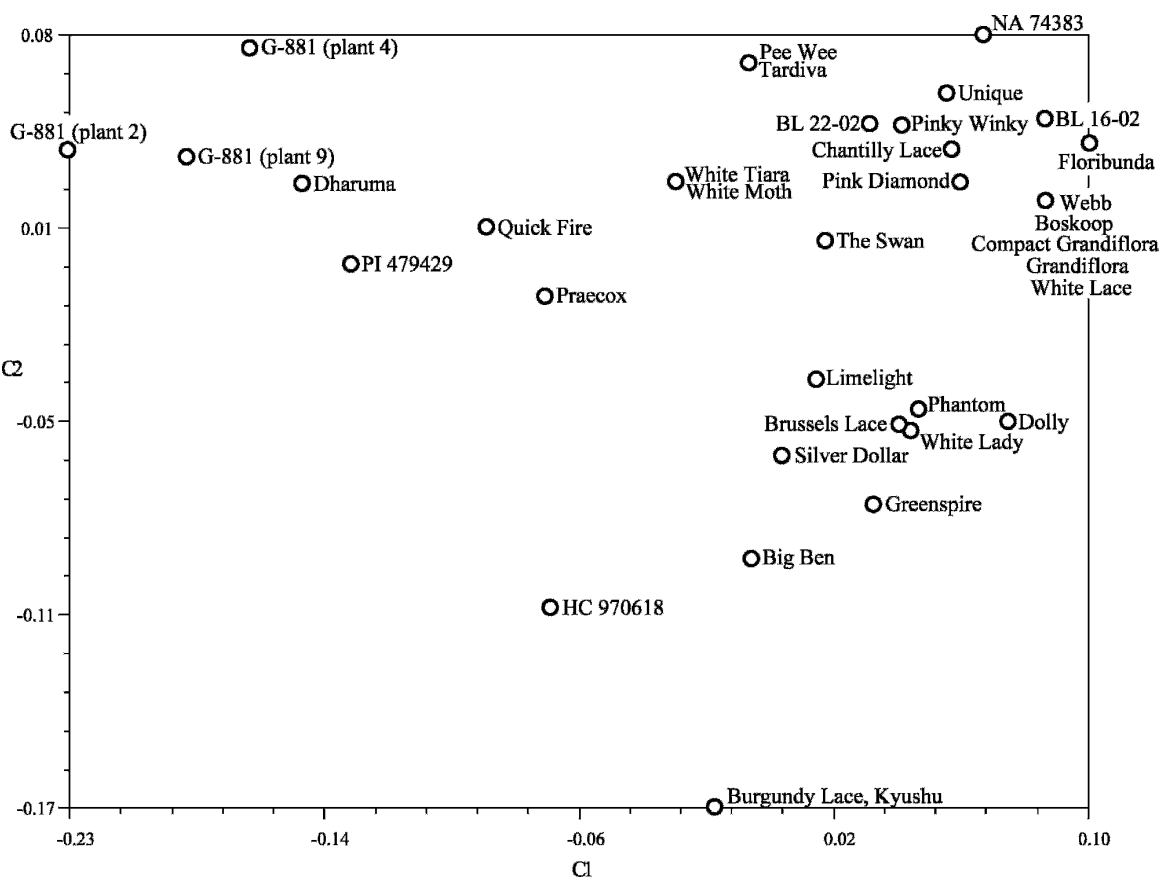

Fig. 2. Principal coordinate analysis (PCoA) derived from Nei's minimum genetic distance matrix of 34 Hydrangea paniculata genotypes, all of which were introduced from Japan or bred from Japanese germplasm. $\mathrm{C} 1$ and $\mathrm{C} 2$ axis represent $42.5 \%$ and $22.8 \%$ of the total genetic diversity, respectively. Three cultivars are listed by their trademarked names: Early Sensation ('Bulk'), Pinky Winky ('DVPinky'), The Swan ('Barbara').

two plants of DJHT 99157 that were examined showed close genetic similarity to each other and to the single BSWJ 3802 plant. The Taiwanese collections were genetically distinct from all other genotypes examined. HC 970618 was collected from the Kii peninsula of Honshu, Japan, in 1997 by Dan Hinkley (Heronswood Nursery, 2003). Although it falls in the same overall grouping with the cultivated members of this species, it shows no close genetic relationship to any other genotypes tested in this study.

One possible source of error in the interpretation of the data from this study is the assumption that all genotypes evaluated were tetraploids. Although the fact that no plant exhibited more than four alleles for any SSR marker might indicate that none of genotypes were hexaploids, six peaks are not expected for a new hexaploid genotype unless it was created from two relatively divergent parents. The number of copies of each allele that was assigned to genotypes based on relative peak height would have been incorrect if some of those genotypes were diploids, triploids, or hexaploids. However, because no unique alleles were introduced or eliminated, only minor changes in the closeness of genetic relationships between specific genotypes would be expected as a result of this possible error.

In summary, SSR markers were used successfully to analyze genetic diversity in $H$. paniculata. In addition to identifying possible mislabeled cultivars, this study provides information about relationships among cultivars and potentially unexploited sources of germplasm for improvement of this popular shrub. It is hoped that this information will provide direction to breeders attempting to develop new, improved forms of $H$. paniculata.

\section{Literature Cited}

Brickell, C.D., B.R. Baum, W.L.A. Hetterscheid, A.C. Leslie, J. McNeill, P. Trehane, F. Vrugtman, and J.H. Wiersema. 2004. International code of nomenclature for cultivated plants. 7th Ed. International Society for Horticultural Science, Acta Horticulturae 647.

Dirr, M.A. 2004. Hydrangeas for American gardens. Timber Press, Portland, OR.

Funamoto, T. and M. Ogawa. 2002. A cytogeographical study in Hydrangea paniculata Sieb. in Japan. Chromosome Sci. 6:73-82.

Funamoto, T. and R. Tanaka. 1988. Karyomorphological studies in some taxa of Hydrangea from Japan. La Kromosomo II 49:1583-1594.

Goudet, J. 1995. FSTAT (Version 1.2): A computer program to calculate F-statistics. J. Hered. 86: 485-486.

Haworth-Booth, M. 1984. The hydrangeas. 5th Ed. Constable and Company, London, UK.

Heronswood Nursery. 2000. Hydrangea paniculata. 8 July 2008. <http://catalogs.google.com/catalogs? id $=$ PCPRkdouJGkC\&pg $=$ PA106\&lpg $=$ PA106\& $\mathrm{dq}=$ hydrangea + paniculata + BSWJ $+3802 \&$ source $=$ web\&ots $=\mathrm{e} 2 \mathrm{~h} 9 \mathrm{yWo} 3 \mathrm{wr} \& \mathrm{sig}=\mathrm{WC}$ fofp $5 \mathrm{Gia} 2$ pg8E-UnQaGiNSJRA\&hl=en\&sa $=$ X\&oi=book result\&resnum $=3 \& \mathrm{ct}=$ result $>$.

Heronswood Nursery. 2003. Hydrangea paniculata. 8 July 2008. <http://catalogs.google.com/catalogs? id=I9M428q2YR4C\&pg=PA75\&lpg=PA75\& $\mathrm{dq}=$ hydrangea + paniculata + DJHT $99157 \&$ source $=$ web\&ots=pDR9_Ybl1K\&sig=fJVBJcOqOavYy
COluHWT2d1GmBE\&hl=en\&sa $=$ X\&oi $=$ book result\&resnum $=1 \& \mathrm{ct}=$ result $/>$.

Langella, O. 2002. POPULATIONS, a free population genetics software. 28 Feb. 2006. <http:// www.pge.cnrs-gif.fr/bioinfo/populations/index. php?lang $=$ en $\&$ doc $=$ populations $>$.

Leeson, T., S. Bale, T. Jones, W. Dunwell, and R. McNiel. 2004. Extended vase life for cut stems of Hydrangea paniculata. Proc. Southern Nursery Res. Conf. 49:624-626.

Mallet, C. 1994. Hydrangeas: Species and cultivars. Vol. 2. Centre d'Art Floral, Varengeville, France.

Mallet, C., R. Mallet, and H. van Trier. 1992. Hydrangeas: Species and cultivars. Vol. 1. Centre d'Art Floral, Varengeville, France.

McClintock, E. 1957. A monograph of the genus Hydrangea. Proc. Calif. Acad. Sci. 29:147256.

Nei, M. 1972. Genetic distance between populations. Amer. Nat. 106:283-292.

Page, R.D. 1996. TreeView: An application to display phylogenetic trees on personal computers. Comput. Appl. Biosci. 12:357358.

Reed, S.M. 2004. Self-incompatiblity and time of stigma receptivity in two species of Hydrangea. HortScience 39:312-315.

Reed, S.M. and T.A. Rinehart. 2007. Simple sequence repeat marker analysis of genetic relationships within Hydrangea macrophylla. J. Amer. Soc. Hort. Sci. 132:341-351.

Rinehart, T.A., B.E. Scheffler, and S.M. Reed. 2006. Genetic diversity estimates for the genus Hydrangea and development of a molecular key based on SSR. J. Amer. Soc. Hort. Sci. 131:787-797.

Rohlf, F.J. 1992. NTSYS-pc numerical taxonomy and multivariate analysis system, version 1.70 . Exeter Software, Setauket, NY

Rose, N., D. Selinger, and J. Whitman. 2001. Growing shrubs and trees in cold climates. Contemporary Books, Chicago, IL.

Saitou, N. and M. Nei. 1987. The neighbor-joining method: A new method for reconstructing phylogenetic trees. Mol. Biol. Evol. 4:406425 .

Sax, K. 1931. Chromosome numbers in the ligneous Saxifragaceae. J. Arnold Arbor. 12:198206.

U.S. Patent Office. 2002. Hydrangea plant named 'Limelight'. 28 July 2008. <http://patft.uspto. gov/netacgi/nph-Parser?Sect $1=$ PTO2\&Sect $2=$ HITOFF \&p $=1 \& u=\% 2$ Fnetahtml $\% 2$ FPTO $\% 2 \mathrm{~F}$ search-bool.html\&r=1\&f=G\&l=50\&co1=AND $\& \mathrm{~d}=\mathrm{PTXT} \& \mathrm{~s} 1=\mathrm{PP} 12874 \&$ OS $=\mathrm{PP} 12874 \& \mathrm{RS}=$ PP12874>.

U.S. Patent Office. 2003. Hydrangea plant named 'Barbara'. 28 July 2008. < http://patft.uspto.gov/ netacgi/nph-Parser?Sect $1=$ PTO2\&Sect2=HIT OFF $\& p=1 \& u=\% 2$ Fnetahtml $\% 2$ FPTO $\% 2$ Fsearchbool.html\& $\mathrm{r}=1 \& \mathrm{f}=\mathrm{G} \& \mathrm{l}=50 \& \mathrm{co} 1=\mathrm{AND} \& \mathrm{~d}=$ PTXT\&s $1=$ PP13606\&OS $=$ PP13606\&RS $=$ PP13606>.

van Gelderen, C.J. and D.M. van Gelderen. 2004 Encyclopedia of hydrangeas. Timber Press, Portland, OR.

Van Laere, K., J. Van Huylenbroeck, and E. Van Bockstaele. 2008. Karyotype analysis and physical mapping of 45S rRNA in Hydrangea species by fluorescence in situ hybridization. Plant Breed. 127:301-307.

Zonneveld, B.J.M. 2004. Genome size in Hydrangea, p. 245-251. In: van Gelderen, C.J. and D.M. van Gelderen (eds.). Encyclopedia of hydrangeas. Timber Press, Portland, OR 